\title{
THE CZECH PENSION SYSTEM AND THE PERSPECTIVES OF ITS REFORM
}

\author{
Michal Slavík*
}

\begin{abstract}
:
This essay describes the Czech pension system, provides a brief history of its modern transformation and mentions some of its drawbacks which should be the subject of a future policy debate. Particular attention is devoted to the third pillar and to the importance of a well-functioning capital market as one of the key conditions for the further development of funded pillars. The question of the timing of the enhancement of the funded pillars in a robustly growing economy with a limited capital market is opened. A lack of new private shares and bonds issues on the domestic capital market may be one of the arguments for postponement of the funded pillars' strengthening. A focus of policymakers who will set up the pension system reform strategy should be concentrated on comparing transitional and transaction costs of each reform alternative and on the building of an efficient regulatory and supervisory infrastructure. They should, instead of enforcing involuntary savings in pension funds, seek measures that will help to create a savings-friendly and growth-oriented economic environment.
\end{abstract}

Keywords: pension system, pension reform, social security

JEL Classification: G18, G23, H55

\section{Introduction}

The pension system and its reform were a subject of a very intensive debate in the Czech Republic in the last couple of years. The commonly shared view that the current system should be modified has not yet resulted in any significant changes in the pension system. However, several measures to support the stability of the first pay-as-you-go (PAYG) pillar have been implemented and consequently this pillar seems to stabilised in the short term. A danger from the ageing of the Czech population emerges rather in the longer term after year 2035 (see e.g. Bezděk-Dybczak-

\footnotetext{
*) Faculty of Social Sciences, Charles University, Prague. The views expressed here are those of the author and do not necessarily have to correspond to the views of any institution the author may be associated with. E-mail: michal.slavik@seznam.cz. I would like to thank to Jaromír Doležal and Bill Kerr for helpful comments and suggestions. All mistakes are nevertheless mine.
} 
Krejdl, 2003, who investigated fiscal implications of ageing in the Czech Republic), but further measures should be welcomed.

This paper aims to give a short overview of the development of the current pension system in the Czech Republic, discusses the possible options for the future and points out some of the factors that could be relevant while considering the setting of the pension reform strategy in the Czech Republic. More stress will be put on the issues that should be taken into account in a post-transformation economy while choosing a proper reform strategy. I feel that the institutional setting of the capital market and the acquired historical experience of the population should be taken more into account.

Attention will be paid to the third pillar, because there may be a lot of potential in its future strengthening and expansion. The first PAYG pillar works well, although some problem can be seen in too strong equalisation of pension benefits. Measures that would lead to a higher correlation between contributions paid during the productive phase of any human life span and benefits received after retirement would be generally welcomed. One of the possible ways to achieve this goal would be to shift the first pillar to a notional defined-contribution (NDC) system, but other routes could have a similar impact as well. A factor that complicates such a step is a high share of non old-age pensions in the total expenditures of the current first pillar.

The paper has the following structure: first, I concentrate on the existing situation both in the first and the third pillar, I touch on their recent history and mention some of the possibly interesting issues that may be relevant for a pension reform strategy. Second, I briefly introduce current proposals of parliamentary parties. Third, I discuss two of the issues that are related to timing of the reform and to the performance of the pension funds and long-term stability. Finally, I come to the conclusion of the paper.

\section{The Development in the 1990 s and the Current Situation}

The current pension system in the Czech Republic consists of two pillars: a compulsory first PAYG pillar and a voluntary funded third pillar. There is still no compulsory funded (second) pillar there. The first PAYG pillar provides beside the oldage pension also other pension benefits, i.e. full and partial disability, widow's and orphan's pensions. The old-age pensions represented around $70 \%$ and the other pension benefits the remaining $30 \%$ of the PAYG expenditures as documented (e.g. in Bezděk, 2001). The second compulsory funded pillar has not been established yet, although there had been attempts to introduce the second pillar in the form of a funded system based on the occupational principle. All these proposals were rejected. The first pillar is a traditional social security scheme, which had been inherited from the planned economy; the third pillar is historically a younger one, because its establishment relied on the capital market development.

\subsection{The First PAYG Pillar}

The pension system, inherited from the planned economy regime was a PAYG defined benefit (DB) system with an absolute role of the state in providing the social 
security for retired people. The role of the individual responsibility in the planned economy was suppressed, similarly to the role of money or financial savings. The distribution of salaries was driven in those times by political factors and not by productivity of the particular worker. The collapse of the planned economy called for changes of the pension system, because some of its features were no longer acceptable (e.g. different treatment of different professional groups according to the retirement age, etc.). The radical economic reform measures in the early 1990 s that inter alia consisted of price liberalization and privatization of the public property shrank the real value of the existing financial savings of the population. The substantial rise in the price level of consumer goods and services partially evened out the difference of the real values between the pension benefits for those who were already retired and those close to retirement and led to an equalization of pension benefits. The public perceived this as generally acceptable, because the distribution of salaries during the planned economy was not felt as fair. The redistribution still included in the first pillar can be depicted using Table 1. It compares the position of a person in the income distribution during productive period (in the first column) and the pension benefits in the retirement period (in the second and third columns):

Table 1

\begin{tabular}{|c|c|c|}
\hline Personal wage/average wage & Pension benefit/personal wage & Personal benefit/average wage \\
\hline $50 \%$ & $77 \%$ & $38 \%$ \\
$100 \%$ & $48 \%$ & $48 \%$ \\
$150 \%$ & $34 \%$ & $51 \%$ \\
$200 \%$ & $27 \%$ & $54 \%$ \\
\hline
\end{tabular}

Source: World Bank, 2001.

The table shows that a person who had been working for an average wage (i.e. $100 \%$ in the personal wage/average wage column) receives a pension benefit equal to $48 \%$ of previous personal wage when retiring. A person who had been earning double the average wage receives only $27 \%$ of personal wage after retirement. The strong redistribution and equalization of pension benefits is - most clearly visible from the third column of the table; people who had been earning $100 \%, 150 \%$ and $200 \%$ of the average wage get from the first PAYG pillar almost the same pension benefits, which are on the level of $48 \%, 51 \%$ and $54 \%$ of the average wage.

The first governments after the changeover in 1989, which carried out radical economic reform measures were sensitive to the social impact on the retired population. The governments prevented retired people from a significant loss of the real value of pension benefits, as a consequence of radical reform measures, and they adjusted the pensions according to changes of the CPI and the nominal wages growths. The indexation scheme was rather complicated, but on average the pension benefits have been adjusted fully for the CPI rises plus $87 \%$ of the average real wage increases. The PAYG system was in surplus for - several consecutive years after 1989, but the revenues were used for other fiscal purposes because the first pillar was fully integrated in the state budget. Later on, a partial separation of the PAYG from the state budget was carried out and the so-called "pension account" 
was set up. This account was (and still is) a part of the state budget. Its semi-separation made it more visual and improved overall readability and transparency of the PAYG. The surpluses were subject to several factors, but probably the main ones were a very low unemployment rate (and consequently sufficiently high volume of the pension system revenues) and a fast growth in nominal wages in those years. The very first reform years were devoted more to changing the ownership in the economy than to restructuring the supply side. Slow adjustment of the supply side resulted in a situation in which ineffective production was carried on and closing down of loss-making factories was postponed; this harmed the growth perspectives of the economy, but created an undisturbed environment on the Czech labour market because the over-employment in certain sectors of the economy was reduced only gradually.

The first pillar had been balanced or in surplus until 1997, when the first deficit of approximately $-0.5 \%$ of GDP on the PAYG pension account occurred. The deficit tendencies continually worsened until 2000 when the deficit doubled to $-0.9 \%$ of GDP. The main source of this could be linked to the cyclical development and to the process of real adjustment and restructuring of the supply side of the economy which resulted both in higher unemployment (and hence lower pension system revenues) and in increasing outflow of older employees who tried to solved their situation on the labour market by seeking early retirements (and hence higher pension system expenditures). The early retirements were easily accessible and served to solve sudden unemployment of people close to their retirement age who would hardly have found a new job. ${ }^{1)}$

The government fixed the imbalance of the PAYG by a package of parametrical measures that consisted of increasing the contributions paid into the pension system, broadening the base for calculation of the contributions (resulting in higher contributions from self employed persons), increasing the age when a person is qualified to retire and decreasing the attractiveness of early retirements.

\subsection{The Attempts to Introduce the Second Pillar}

The government planned to introduce the second pillar that would be based on occupational pension schemes. Some preliminary work had been done in 1999 and 2000 , but these proposals were later abandoned, mainly because it would have endangered the stability of the third, already existing, pillar by decreasing the volume of voluntary contributions. Establishing new pension funds, which would not be open to the general public (as they are in the third pillar), but on an occupational basis only to employees of a particular employer would result in additional fixed costs and hence lower profits for the participants. The companies that would be large enough to run or support the emergence of such occupational funds were already offering some bonus schemes for their employees using the existing possibilities in the third pillar. No other attempt to introduce a compulsory funded pillar has

1) Surprisingly low official unemployment rates until the middle of the 1990s (by some people called the "Czech transformation miracle") were accompanied by a voluntary outflow of older people from the labour market thanks to an almost automatic qualification for an untimely retirement. 
yet materialized. The current debate on the pension reform, however, discusses some possibilities in this area. The idea of occupational schemes has nevertheless (and fortunately) been abandoned and it is likely that a possible introduction of the second pillar will be based on the already existing infrastructure of the third pillar.

\subsection{The Third Pillar and the Capital Market}

A voluntary third pillar, which would supplement the first PAYG pillar, was created in 1994. The Czech Republic is one of the first transformation countries to introduce an additional pension pillar. This pillar is a defined contribution (DC) system run on a fully funded basis by pension funds and life/capital insurance companies. The third pillar was created relatively soon after the establishment of the capital market.

Since the existence and functioning of the capital market is a necessary condition for a funded pillar, it is important to pay attention to capital market conditions while considering a further pension reform. This is particularly important in the new EU Member States where the capital markets have a short history and might not be mature enough to provide adequate security for cumulated pension savings.

The main point in the modern "history" of the Czech capital market can be summarized in the following points:

- Securities were legally introduced in 1992 when a significant reform of the business law was implemented (a new business law codex - Commercial Code - was approved by the Parliament in 1991 and was binding from $1^{\text {st }}$ January 1992; a Securities Act was approved in 1992 and was binding from $1^{\text {st }}$ January 1993).

- The Prague Stock Exchange was established in November 1992.

- The first 7 securities started trading on the Prague Stock Exchange in April 1993.

- A significant jump of the traded instruments sprung up in June and July 1993 when more than 900 shares of privatized companies from the first wave of the voucher privatization were launched to the Prague Stock Exchange.

- The other increase of the volume of traded securities followed in January 1995 when more than 600 shares from the second wave of the voucher privatization were launched in the secondary market.

- Problems of the liquidity of the voucher-privatization securities had to be solved during 1997 when the Prague Stock Exchange excluded approximately 1,300 shares (out of about 1,500) from the market.

- Since that time, the number of traded securities is decreasing, but the market concentrates on a narrower segment of them, which positively increased the liquidity and transparency of the market price by those securities.

The expansion of the state/public debt was rather slow in the beginning of $1990 \mathrm{~s}$ (see Figure 1); the governments up to 1997 tried to maintain the fiscal discipline of the public sector and did not allow the expansion of explicit debt, which would materialize in a growth of the public debt instruments on the domestic capital market. The situation has changed after the left-oriented governments took over the economic policy setting. During the last years of the 1990s and the beginning of this decade, the governments stimulated the economy by expansionary and debt inducing policies to recover from the previous economic downturn. At the same time, 
the process of clearing the hidden burden started and a significant part of the previous government's non-explicit liabilities was turned over into the state bills or bonds. This created a sufficient supply of government bonds both on the primary and secondary markets, and counterweighted the trend at the stock market, where the amount of traded instruments constantly shrank.

Figure 1

State Debt and Instruments Used for its Financing in 1993-2005 (in billions of CZK)

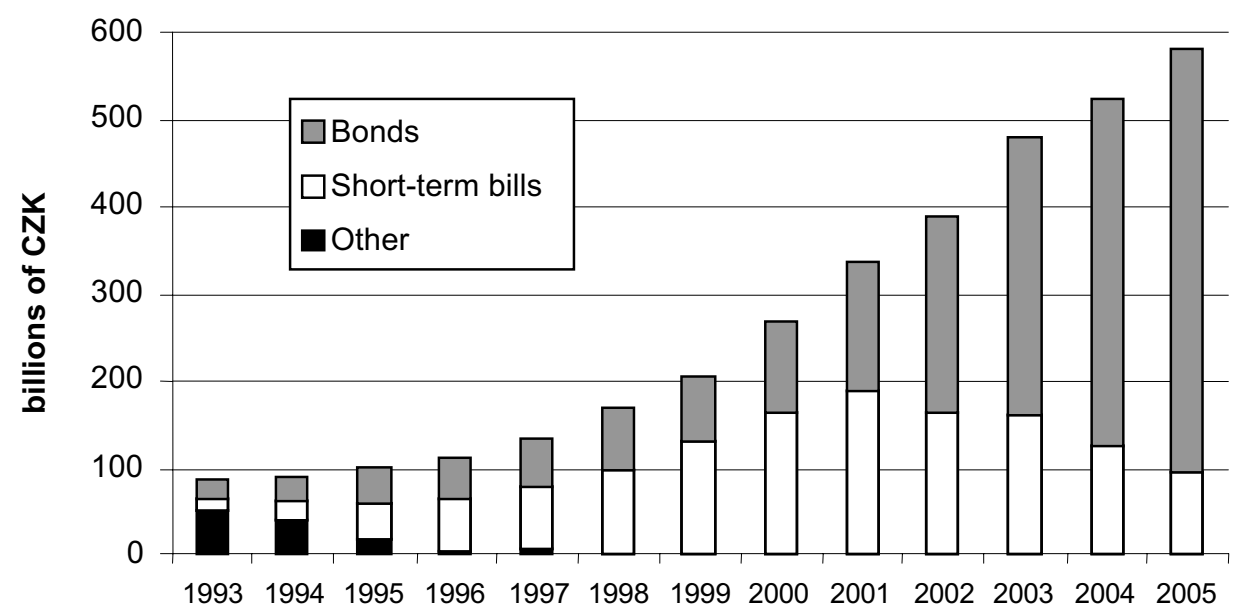

Source: Ministry of Finance, 2006.

Nowadays, around three million citizens (out of 5.1 million citizens constituting the labour force) take part in the third voluntary pension pillar. The factors behind this relatively high number are a state allowance and a tax advantage, since a part of the contributions can be deduced from the personal income tax base. These two factors stimulate the participation of a large number of people, but at the same time they lead to a low volume of contributions. The majority of contributors uses the third pillar as a form of savings just because of this state allowance ${ }^{2)}$ and chooses the amount of their contribution such that it maximizes the allowance.

The third factor affecting the high participation is support of the third pillar from some employers; they introduced (also mainly for tax reasons) motivation programmes for their employees and pay a part of their employees' contributions to the pension funds or the insurance companies that run pension insurance. ${ }^{3)}$ Currently, ap-

2) The state allowance has the form of a contribution paid by the state for a participant to his individual pension account in a pension fund. The allowance has an upper limit and depends on the contribution paid by the participant. The annual volume of the state allowances was roughly 3.2 billions of CZK (i.e. $0.1 \%$ of GDP in 2004).

3) The total monthly contribution to an individual pension account consists therefore of three parts: a contribution paid by employee (from his net income), a contribution paid by employer (obligatory taxable cost for companies) and a state allowance. 
proximately just over one quarter of all participants are, according to the Ministry of Finance, supported by their employer through some benefit programme. Their own contribution to the system is often less than the contribution paid by the employer for them.

The third pillar shows two main troubles: low contributions and ageing of the clients. The first problem can be seen from Table 2 that shows the distribution of the current monthly contributions to the third pillar:

Table 2

\begin{tabular}{|c|c|}
\hline Monthly contribution (in CZK) & Share in total (in \%) \\
\hline $1-99$ & 1.2 \\
$100-199$ & 20.8 \\
$200-299$ & 16.3 \\
$300-399$ & 16.1 \\
$400-499$ & 2.4 \\
$500-599$ & 30.5 \\
$600-999$ & 3.5 \\
$1000-1999$ & 8.8 \\
2000 and more & 0.4 \\
\hline & 100 \\
\hline
\end{tabular}

Source: Ministry of Finance, 2005.

A majority of the people who participate in the third pillar have a monthly contribution less then 600 korunas as it is depicted in the previous table. The average nominal gross wage was roughly 18,000 korunas, so in relative terms the contributions are less than $3.4 \%$ of the gross income. The state allowance is relevant for part of the savings up to 500 korunas; the monthly contributions above 500 korunas qualify only for the maximum state allowance that corresponds to the contribution of 500 korunas. It is therefore not surprising that the most significant group of participants (around $30 \%$ ) maximize the state allowance by paying only 500 korunas. The second biggest group (around $22 \%$ ) are those who pay less than 200 korunas. Only $5 \%$ of participants pay monthly 1,500 korunas, the contribution that fully maximizes the possible tax advantage. These contributions are probably not high enough to cumulate sufficient pension savings. Moreover, an individual saving period is rather short, as depicted in Table 3.

The largest group of participants is aged 50 to 59 years (almost $30 \%$ of all participants in the $3^{\text {rd }}$ pillar). More than one half of the participants are from the age of 40-59, so therefore employees with a relatively shorter time until retirement. The group of the younger employees younger than 30 years of age, on the other hand constitutes only less than $10 \%$ of the participants. Strengthening the participation rate of this part of the working population would be one way to stimulate the volume of savings cumulated in the third pillar and one of the possible options for the pension system improvements. This will not be so easy to implement in practice, because the younger generation face the unfavourable situation in the housing market. The current rigid price regulation of rents and a protection of existing lease- 
holders prevent them from achieving housing for a reasonable price. A lot of them therefore have to solve the situation by buying a flat and taking a mortgage which then significantly limits their idle financial resources for other forms of savings. Another problem is growing household indebtedness; they have already borrowed from the banking sector CZK 330 billion (out of which CZK 210 billion for financing their housing). The rapidly growing indebtedness of households, whose debts already tripled from 2000 (i.e. from CZK 75 billion in January 1993, to CZK 104 billion in January 1999 to CZK 313 billion in January 2005 in nominal terms), may constitute a significant problem not only for the creation of pension savings.

Table 3

\begin{tabular}{|c|c|c|}
\hline $\begin{array}{c}\text { The age structure of } \\
\text { the third pillar }\end{array}$ & Share in total (in \%) & Share in total (in \%) \\
\hline $18-19$ & 0.1 & \\
$20-29$ & 9.7 & 27.5 \\
$30-39$ & 17.6 & \\
$40-49$ & 21.6 & 51.2 \\
$50-59$ & 29.7 & \\
\hline $60-69$ & 14.5 & 21.3 \\
$70-79$ & 5.6 & 100.0 \\
\hline above 80 & 1.2 & \\
\hline & 100.0 & \\
\hline
\end{tabular}

Source: Ministry of Finance, 2005.

The other issue that can be seen in Table 3 is a low proportion of retired people in the third pillar. The vast majority quits the system when they retire by asking for a one-shot settlement, taking out all the saved money at once. Only a minority of participants prefers receiving periodically paid pension benefits. This indicates that the public takes the third pillar more as a tool for short-term savings (to obtain the state allowance) than as a pension system that would be primarily used for securing retired people over a longer time period in their post-productive life.

The assets held by the pension funds are growing well, their y-o-y increase of volume was solid and reached a breathtaking $24 \%$ in the last fiscal year. ${ }^{4)}$ The total assets of the Czech pension funds reached the level of CZK 109 billion (i.e. $3.7 \%$ of GDP) in the first quarter of the year 2005. This number contrasts with CZK 597 billion which were deposited by households in commercial banks in the form of term deposits. The deposits in commercial banks are still the prevailing form of the Czech households' savings. The share of pension fund's assets in the total assets of the

4) This positive achievement may be attributed to the popularization of the pension reform debate in the media and to the effort of the expert group to explain a pension reform to the general public. A lot of citizens started to think more about their security in the retirement age than they had done before. 
financial sector is rather small, constituting just $2.4 \%) .^{5)}$ The structure of their assets is depicted in the following table:

Table 4

\section{Structure of Assets Hold by the Pension Funds}

\begin{tabular}{|l|c|}
\hline Form of assets & Share on total \\
\hline Public debt securities & $53 \%$ \\
\hline Private debt securities & $27 \%$ \\
\hline Bank accounts & $9 \%$ \\
\hline Shares & $7 \%$ \\
\hline Other Assets & $4 \%$ \\
\hline Total & $\mathbf{1 0 0} \%$ \\
\hline
\end{tabular}

Source: Association of Pension Funds (APFCR), data relevant to 30 June 2005.

A large part of the pension funds' total assets is held in government securities (around $53 \%$ ), the private debt instruments form only $27 \%$ and the private shares and the deposits in banks is $9 \%$ of the total funds' assets. This is related to the conditions on the Czech capital market as already mentioned above, where after a huge increase of traded shares from the voucher privatisation, the majority of these shares was pulled off the secondary market and is not publicly traded or is tradable but more or less illiquid. The main market of the Prague Stock Exchange quotes only 34 securities, out of which 25 are public/state bonds and just nine securities are the corporate bonds or shares. Besides the main market, there are two additional markets (the secondary and the free one) with a higher number of securities, but these securities are less liquid and the market price may be harder to determine because they are not traded as often. The pension funds are allowed to invest also into foreign securities which are traded on regulated markets in the OECD countries. However, the appreciation of the domestic currency makes often investments into well-rated and less risky, but low interest-earning foreign instruments, not so lucrative business.

\section{Current Reform Proposals}

The government declare its awareness of the population ageing and the resulting fiscal implications. An intensive debate about a pension system reform has been

5) The biggest proportion of assets in the Czech financial sector is held by the commercial banks: $74.2 \%$, the insurance companies: $7.7 \%$ and the leasing companies $6.4 \%$. The total assets of pension funds $(2.4 \%$ at present) are rather negligible relative to the assets of the whole financial sector. 
taking place in the Czech Republic since the mid-1990s, but has not yet resulted in any significant changes. Several parametric measures were introduced in the years 2003 and 2004. Their aim was predominantly to balance the first pillar. The leading governmental party had planned to change the first pillar with the defined benefit system to a NDC system two or three years ago, but this idea did not find broad support among policy makers. It is necessary to find a wider political consensus on the future form of the pension system among the parliamentary parties that will guarantee that a new pension system will be more politically stable and will not be modified after each election. The government therefore established a working group on preparation of the pension reform in the year 2004. This group, where each parliamentary party has two pension system specialists, was supported by an executive team of experienced experts that was able to simulate suggested scenarios and provide feedback on the parties. The parties could interactively change in several rounds their input policy variables to obtain more preferred results.

Each of the five parliamentary parties introduced its vision of a pension system reform and the team of experts calculated possible impacts of the suggested changes. The experts built up simulation models which were able to cope with the variables that were considered in the scenarios provided by the parties. They focused in their simulations on the replacement ratio and the fiscal balance of the pension system over the period up to the year 2100. But they also investigated many other things related to the pension system and did an extremely useful job. However, the biggest problem so far is that the parties have not been able to get rid of their initial assumptions about the pension reform strategy and no visible convergence between parties' scenarios has yet occurred. Each of the parties is fastened to the view of a pension reform that was presented more than one year ago. The output of simulations, done by the expert team, only led to changes of the parameters that each party had been considering, when it became evident that the previous assumptions of a party were unrealistic.

The five different scenarios suggested by the parliamentary parties, which were under discussion, can be in a simplified way summarized as:

1. equalising of benefits paid from the PAYG pillar at the level of $20 \%$ (!) an average wage and increasing the retirement age up to 71 years at the end of this century; decreasing the compulsory contributions to the first pillar and relying on the voluntary savings (!) in the third pillar,

2. changing of the first pillar from the current $\mathrm{DB}$ to NDC, increasing the retirement age up to 65 years in 2030; guaranteeing that the future pension of any individual will not be lower than 1.2 times the subsistence minimum,

3. possibility to partially opt-out; decreasing the contribution to the first pillar by 8 percentage points by sending them into the funded pillar ${ }^{6}$ (for those people who use this option the total contribution to the pension system will be higher by 2 percentage points), different contributions for already working generations and new generations,

6) The assumption is that the contribution to the pension system will be 28 per cent of the gross income if a person does not take the opt-out and 30 per cent if she does ( $20 \%$ to the first pillar and $10 \%$ to the second pillar). 
4. possibility to partially opt-out, lowering the contribution to the first pillar by 3 percentage points (people who take this option will have to increase their contribution to the third pillar by an additional 6 percentage points, ${ }^{7}$ )

5. parametrical changes of the first pillar, increasing revenue side of the system.

These five scenarios are difficult to compare, because they assume different contributions to the system, different retirement age, etc. For example, the contribution rates (as a percentage of a person's gross income) under different scenarios are summarized in Table 5. The number of the scenario in the first column corresponds to the list of options given above.

Table 5

\begin{tabular}{|l|l|c|}
\hline Scenario & Note & $\begin{array}{c}\text { Assumed contribution } \\
\text { rate (as \% of person's } \\
\text { revenues) }\end{array}$ \\
\hline 1. & An "equal pension" for all & $20.5 \%$ \\
2. & Introducing NDC & $29.6 \%$ \\
3. a & Staying in the $1^{\text {st }}$ pillar & $28.0 \%$ \\
b & Opt-out (the current working generations) & $30.0 \%$ \\
c & Opt-out (generations entering labour market) & $28.0 \%$ \\
4. a & Staying in the 1st pillar & $28.0 \%$ \\
b & Opt-out & $34.0 \%$ \\
5. & Parametrical changes of the current system & $29.6 \%$ \\
\hline Current state & Paid jointly by employer and employee & $28.0 \%$ \\
\hline
\end{tabular}

Source: Hospodářské noviny.

It is hard to comment objectively on the suggested scenarios due to their political nature. Nevertheless, one can point to certain issues that seem to be until now either stressed too often/much or missing in the available analysis:

a) Probably too much attention is devoted to the overall accounting balance of the pension system in the long term and not to the possible impact of each scenario on economic variables, such as the economic output end the employment. The Czech society faced deep structural shocks during the 1990s which resulted in shifts (structural breaks) in trends of demographic variables; e.g. postponing the maternity to a higher age, reducing the number of children per woman, increasing the life expectancy both by significant improvement in the medical standards and the quality of the environment. The currently available demographic projections may be influenced by the very recent data, but some of the newly identified trends may not be permanent as it is nowadays assumed. Furthermore, some authors (e.g. Diamond, 1998, p. 5-5) question the forecasts of variables, such as the mortality rate even in stable economies that did not face such significant structural breaks. Modelling the development of the pension system up to the year 2100 could be useful, but the

7) Those who did not opt-out would pay $28 \%$ of their salary into the first pillar, those who opt-out would pay $25 \%$ to the first pillar and $9 \%$ to the third pillar by having the contribution to the pension system at $34 \%$ of their salary. 
government should rather concentrate on the short to medium-term targets and measures. If we look at the pension system from the point of view of the redistribution of the existing output among the working and the retired generation (see e.g. Eatwell, 2003), any pension system will be automatically balanced in the long run. The increased number of retired people relative to the working population also means an increased number of voters who will influence the structure of the tax system. If a pension system is imbalanced, it is very likely that the missing revenues that balance the system will be gained from additional taxation. The discussion on pension reform should focus more on the economic output than on the redistribution (which assumes that the output is somehow externally given).

b) It seems that there is too much enthusiasm about the funded pillars in the Czech Republic these days. The existing pension funds and their administrators are creating an illusion that the only way to solve the "ageing problem" is via higher contributions to the pension funds (it is not surprising, since the fund administrators are remunerated depending on many factors that constitute the fund's annual profit, one of which is the volume of administrated assets). The pension funds' administrators are spreading some of the myth, interestingly questioned (e.g. in Barr, 2000); one of the most frequent is the belief that the funded schemes are less vulnerable to the ageing problem. Some defect of the running discussion is the fact that too many statements are taken for granted without being seriously empirically tested. Some conclusions that are taken from countries with different financial and capital markets can be perfect there, but misleading in countries under different conditions. For example, one of the frequently mentioned assumptions is the declaration that the funded pension funds stimulate economic growth (compared to the PAYG). This may perfectly hold true if the pension funds stimulate corporate investment activity, but should probably be tested and considered carefully in countries where funds invest their assets mainly into government bonds.

c) Too much emphasis is placed on the quantitative side, e.g. how much contribution will go to the funds and how much to the first PAYG pillar. On the other hand, a deeper discussion on the cost effectiveness, profitability and efficient regulation of the pension funds/insurance companies is still missing. Nobody has been investigating the investment perspectives of the funds on the domestic capital market (assuming a large inflow of contributions paid into the third pillar if some of the suggested scenarios will be finally approved). If the financial stability of the system should be ensured in the long term, an efficient regulation and supervision is necessary. These activities are not costless and any reform scenario that counts on a substantial development of the funded pillar(s) should include a regulatory framework which would prevent future collapse of pension funds. The government should also define clearly its responsibility and authority in the case of a fund's bankruptcy or an occurrence of heavy losses. Will the participants be compensated, how much and from which sources? These are the questions that should be answered, but no consensus has yet emerged.

d) Practically all parties involved in the pension reform preparation assume an increase in the retirement age. This would be a sufficient measure to increase the revenues of the pension system only if these people would be able to keep their jobs or find new ones in the event of unemployment. The current situation on the Czech labour market and a certain, although legally banned but in reality existing, age 
discrimination nevertheless does not give too many chances to older people to find a new job. Carrying out a pension reform that increases the retirement age should be accompanied by measures that avoid rising unemployment of the people who are close to their retirement. If this will not be the case, the seeming improvements in the balance of the old-age part of the pension system will be accompanied either by growing expenditures in other pension schemes (i.e. disability pensions) or social benefits (higher volume of unemployment benefits). So far, any measures that would try to solve this problem have not been seriously discussed; the public pension debate may seem for some observers in the Czech Republic to be immersed in itself ignoring its consequences on the labour and the capital markets.

\section{Some Open Issues}

There are other issues related to a pension reform there that have not yet been solved. I feel that the economic dimension of the planned/suggested pension system reforms have been somehow insufficiently examined. For example, two topics that may be mentioned are the timing of the funded pillars strengthening and the performance of pension funds in the last years.

\subsection{Is It the Right Time for Introducing or Strengthening the Funded Pillar(s) now?}

The new EU Member States are now in the process of a real economic convergence to the economic level standards of the old EU Member States. This convergence can be perceived as a transition between two steady states. The process of real convergence come through higher economic growth rates in the new EU Member States. This is often accompanied by a tendency towards a long-term appreciation of the domestic currencies. These two factors, namely the higher domestic economic growth rates and the appreciation of the domestic currency should make the investments into domestic securities more preferable than investing abroad. But what to do if the domestic capital market is not sufficiently developed to offer enough investment possibilities for pension funds' administrators? Pension funds' managers can always use hedging to eliminate the exchange rate risk and buy the assets abroad, but is this strategy beneficial to the local economy?

The situation on the Czech capital market is, probably due to historical reasons, such that there is a minimum of private companies that would use the stock exchange as a place to obtain additional capital (the major financing channel of companies goes through the commercial banks). Consequently, almost all new securities issues in the last years were done by the government or public entities, such as the European Investment Bank. New issues of corporate shares or bonds are, generally speaking, missing in Prague. Moreover, the existing corporate securities are often pulled from the market when one of the shareholders gets the majority stake (due to the privatisation of remaining state stake or squeezing out of other minority shareholders). The policymakers allow changing the law to make these squeezing outs easier for the major shareholder which further stimulates the outflow of securities from the secondary market. The fact, that the price of such squeezed-out assets is 
determined solely by the majority shareholder and its valuator, may seriously undermine the confidence in the domestic capital market.

If the government has been the main issuer of the securities and given the Stability and Growth Pact that limits the government's future borrowings, there may not be theoretically a sufficient stream of new debt instruments supplied or offered to the domestic capital market. If a pension reform forces the creation of funded savings in the second pillar, it may result in the stimulation of a price bubble of the existing domestic securities. The pension funds will have to allocate a larger stream of contributions on the capital market. Given a limited amount of domestic securities, they will likely increase their demand for the outstanding ones, which will ceteris paribus result in the increase of the assets prices. This assets prices growth may continue until the stream of additional contributions is sufficient or until the funds start to look for investments abroad (e.g. when the exchange rate stops to appreciate). The bubble in assets prices may then quickly deflate and cause a potential financial and political instability.

This would imply either very gradual reform strategy, where the weight of funded pillars would be growing moderately, or a fast elimination of the exchange rate risk - i.e. a rapid adoption of the euro that would allow the domestic savings to be allocated in the euro zone without the exchange rate risk (and additional hedging costs) preventing a formation of an asset price bubble on the domestic capital market. Unfortunately, some of the current reform proposals (backed by a mighty lobby of pension funds' administrators) try to strengthen the role of funded savings rather faster without eliminating the risks.

\subsection{Profitability of Pension Funds}

The last available data show a not very high profitability of pension funds over the period from the year 2000 to 2005. The following table summarizes the average yields of 11 existing pension funds (without the state allowance) from the participants' perspective. ${ }^{8}$ The nominal yield fluctuated between $3.2 \%$ and $4.2 \%$ in the last six years, but due to the CPI inflation volatility, the real participants' annual gains were between $-0.7 \%$ and $3.1 \%$. A remarkably low real gains in the years 2000 and 2004, and even a loss in 2001 may stem from the structure of pension funds' portfolios and a high share of fixed coupon state bonds (there are no index linked state bonds in the Czech Republic). Unexpectedly higher inflation by this structure of assets then naturally results in a real loss.

When summing up the average real yield of pension funds over the period 2000 $-2005^{9)}$ we obtain an annual real interest rate of just $1.7 \%$. Such a low real interest rate does not at all correspond to the participants' original expectations, formed at the time when they set up their individual pension contracts. This disappointing result is counterbalanced by the state allowance, so the overall performance of the savings cumulated in the third pillars is acceptable for the participants. From the economic point of view, it is, however, rather questionable whether it is worth sup-

\footnotetext{
8) i.e. what was added to their individual pension accounts net of the state allowance

9) i.e. the last row of Table 6 .
} 
Table 6

Average Yield in \% (without state allowance) of Pension Funds

\begin{tabular}{|l|c|c|c|c|c|c|}
\hline Year & 2000 & 2001 & 2002 & 2003 & 2004 & 2005 \\
\hline Average nominal yield & 4.2 & 4.0 & 3.7 & 3.2 & 3.6 & 4.1 \\
Average CPI inflation & 3.9 & 4.7 & 1.8 & 0.1 & 2.8 & 1.9 \\
Average real yield & 0.3 & -0.7 & 1.9 & 3.1 & 0.8 & 2.2 \\
\hline
\end{tabular}

Source: Association of Pension Funds, (APFCR), Ministry of Finance and own calculation

porting the third pillar from the state budget in this way. The state allowance that goes to this pillar is then obviously missing in the first PAYG pillar. The government, due to this allowance system, in fact, takes a part of the investment risk from the private managements of the pension funds. On the one hand, this can be a subject of a certain criticism; on the other hand, it is a way to counterbalance the high redistribution included in the first pillar, since the participants of the third pillar are more likely the people earning wages above the median, so they are drawn from the "richer" part of the population.

Developing further the third pillar or establishing a new second pillar will be accompanied by the increase of the total volume of assets cumulated in the pension funds. It is an important issue whether the increasing amount of sources available to the fund managers is positively or negatively related to the yield obtained ex-post from those assets. Intuitively, if neglecting the fixed cost related to the management of the pension funds, the volume of assets administered by the funds should negatively influence their yields. The funds' managers maximize the yield, given existing constraints - e.g. limits on risk and reliability of instruments. When administering lower volumes, they should pick up the most profitable instruments that satisfy the given constraints. By increasing the volume of the assets, less profitable instruments will be available (the better ones should be already in their portfolios). If this hypothesis were right, it would result in the expectation that the yields, which have been achieved in the past years, may decline even further. This may create a strong disillusion from the third (or eventually the second) pillar's performance and lead potentially to an instability. Any serious pension reform attempt should be therefore accompanied by a sensitivity analysis of the chosen strategy on the possible yields of assets. Unfortunately, no such analysis is available at the moment in the Czech Republic and the rate of yields is taken for granted practically in all existing considerations.

\section{Conclusion}

The reform of the pension system is one of the hottest topics in the Czech Republic. The government established an expert group supported by the executive team that quantified reform scenarios of each parliamentary party. The team of experts has done very useful work which made the assumptions of parties more realistic. Nonetheless, the main drawback of the situation is the fact that scenarios of the parties are not convergent to a mutual compromise. Each of the parties was improving its reform proposal and waiting for the next elections, which took place in the 
middle of 2006. The range of offered proposals is broad and heterogeneous, which may prevent finding a wider agreement.

I think that there is probably too much focus on the future financial balance of the pension system in the current debate in our country. This ignores the fact that there are automatic mechanisms that prevent the social security system from being imbalanced in the long-run. The ageing of the population is the same process as the ageing of voters. The preferences of the society will shift to an older median voter accordingly and the society will find a solution that balances the system through taxes or expenditure measures (i.e. cutting other public expenditures and forwarding them into the security system; in other words, the structure of public expenditures will be definitely changed in favour of older citizens and all simulations which take the structure and level of non-pension related public expenditures at today's level for granted for the future might be providing wrong predictions).

It is questionable if we really need a "big" pension reform in the short run in the Czech Republic. What we probably need soon is a change of the first PAYG pillar, which should correct the excessive redistribution inside one generation. There should be a higher correlation between what a person has paid into the first pillar for his productive life and what he will gain afterward when retiring (increasing this correlation may also stimulate willingness to pay contributions to the first pillar by those who are able to determine the size of their contributions). The other needed thing is support for a politically and financially stable economic environment, which favours voluntary savings rather than debt-increasing consumption. The increasing indebtedness of people in their productive period may be a threat not just to the pension system. There are many possible ways that contribute to this goal: for example through improving the housing market, which will reduce rentals and shifts supply of available flats up; through a more responsible tax policy, more stable tax and legal system or a displacement of extremist parties from the political system. If the parties fail to reach a consensus on the "big pension reform", they should better try to find agreements on these smaller steps.

\section{References}

ČNB (2004), “The Financial Stability Report 2004”, December 2004. Prague: ČNB.

Barr, N. (2000), "Reforming Pensions: Myth, Truths, and Policy Choices”. IMF Working Paper 139.

Bezděk, V., Dybczak, K., Krejdl, A. (2003), Fiscal Implications of Population Ageing. Finance a úvěr, Vol. 53.

Bezděk, V. (2000), Státní penzijní systém v České republice. Prague: ČNB (in Czech). (2001), O jednom z možných scénářu reformy penzijního systému v České republice. Politická ekonomie, 49 (2) (in Czech).

Davis, E. P. (1998), "Policy and Implementation Issues in Reforming Pension System". EBRD, Working Paper No. 31, August 1998.

Diamond, P. (1998), "The Economics of Social Security Reform". NBER WP 6719, September 1998.

Eatwell, J. (2003), The Anatomy of the Pension "Crisis" and the Three Fallacies on Pensions. CERF.

Hospodářské noviny, 14. 4. 2005, pp. 8-9. 
Kohl, R., O'Brian, P. (1998), “The Macroeconomics of Ageing, Pensions and Savings: A Survey”. Economics Department Working Papers No. 200. Paris: OECD.

Kubíček, J. (2004), "Fondový penzijní systém v konvergující ekonomice“. Institut pro ekonomickou a ekologickou politiku, WP 1/2004 (in Czech).

Mora, M. (1999), "Pension Policy in the Czech Republic: Lessons from a Comparative Study with Hungary and Poland". Europa-Kolleg Hamburg, October 1999.

Oksanen, H. (2004), "Pension Reforms: an Illustrated Basic Analysis". European Commission Economic Papers, No. 201.

Schneider, O. (1996), "The Harmonization of Public Pension Schemes - Perfect and Imperfect Labour Mobility Cases". CERGE, WP 102.

Stanko, D. (2003), "Polish Pension Funds, Does the System Work? Cost Efficiency and Performance Measurement Issues". The Pensions Institute, Birbeck College, Discussion Paper PI0302.

World Bank (2001), Technical Assistance Report. May 2001. Washington: World Bank. 